Historic, Archive Document

Do not assume content reflects current scientific knowledge, policies, or practices. 



\section{LILIES DIRECT FROM THE GROWER \\ Wholesale Price List}

Brownii

Candidum, under 8 in.

Candicium, 8 to 9 in.

Candidum, 9 to 11 in.

Chalcedonicum

Davuricum 1st

Davuricum, flowering

Easter, $1 / 2$ in. diam. a

Easter, $1 / 2$ to 1 in. diam.

Easter, 3 to 4 in. cir.

Easter, 4 to 6 in. cir.

Easter, 6 to 7 in. cir.

Easter, 7 to 9 in. cir.

Henryi, 6-7 in

Henryi, $\pi / 8$ in.

Henryi, 8-9 in.

Henryi, 9-11 in

Monadelphum Szovitzianum, 1.50

Pardalinum, small

Pardalinum, large

Regale, $3 / 8$ to $1 / 2$ in. diam.

Regale, $1 / 2$ to $3 / 4$ in. diam.

Regale, 2 to 3 in. Circ.

Regale, 3 to 4 in. Circ.

3.00
35

.35

.35
100

Each

agea

$17.50 \quad 150.00$

$20.00 \quad 175.00$

$25.00 \quad 200.00$

$2.00 \quad 22.00$

$\begin{array}{llll}.30 & 3.00 & 20.00 & 150.00\end{array}$

$1.50 \quad 10.00$

$1.50 \quad 10.00$

$2.00 \quad 15.00$

$4.00 \quad 35.00$

$6.00 \quad 50.00$

$7.50 \quad 75.00$

$10.00 \quad 90.00$

$35.00 \quad 300.00$

$37.50 \quad 325.00$

$40.00 \quad 350.00$

$45 . .00$

400.00

15.00

$2.00 \quad 15.00$

3.00

20.00

9.50

17.00

50.00

75.00
Regale, 4 to 5 in. Circ.

Each

Regale, 5 to 6 in. Circ.

Regale, 6 to 7 in. Circ.

Regale, 7 to 8 in. Circ.

Regale, 8 to 9 in. Circ.

Regale, 9 to 11 in. Circ.

Speciosum

Sargentiae

Tenuifolium, Blooming

Tenuifolium, 2 years old

Tiger

Umbellatum, 1st

Umbellatum, 2nd

Willmottiae, Blooming

Willmottiae, Large

Hyacinthus Candicans

English Iris. Blue

English Iris, Mt. Blanc White

250 at 1000 rate. Special price in lots of 5000 or over.

TERMS: Cash with order, unless you have an established credit with us. F. O. B. here.

Candidums, delivered, August-September.

Easter, delivered, September-Oetober.

Others, delivered, October-November.

\section{SHEFFIELD BULB FARM}

" Burton, Washington 


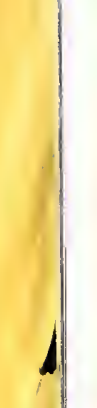

